\title{
Use of a Plastic Rain Shield Reduces Fruit Decay and Need for Fungicides in Sweet Cherry
}

Jorunn Børve, The Norwegian Crop Research Institute, Ullensvang Research Centre, N-5781 Lofthus, Norway; and Arne Stensvand, The Norwegian Crop Research Institute, Plant Protection Centre, Høgskoleveien 7, N-1432 Ås, Norway

\begin{abstract}
Børve, J., and Stensvand, A. 2003. Use of a plastic rain shield reduces fruit decay and need for fungicides in sweet cherry. Plant Dis. 87:523-528.

It has been shown previously that covering sweet cherry trees (Prunus avium L.) with rain shields made of polyethylene or other waterproof, light-transmitting material prior to harvest to prevent fruit cracking will reduce fruit decay by various fungi. In the present work, the effects of extending the covering period on fruit decay, fruit quality, and the potential reduction in number of fungicide applications were investigated. In six of eight trials, there were significant reductions in fruit decay in covered fruit compared with fruit that were not covered. The most prevalent fruit-decaying fungi were Monilinia laxa and Botrytis cinerea. Mucor piriformis and Colletotrichum gloeosporioides occurred in high amounts in one trial each. The treatments included covering during rain periods until harvest was over from (i) bloom (bloom-cover), (ii) 6 to 7 weeks prior to harvest (early-fruit-cover), (iii) 3 to 4 weeks prior to harvest (late-fruitcover), and (iv) not covered. In two trials, the number of fungicide applications was similar between different covering times (bloom-cover not included), and in one trial no fungicides were applied at all (all treatments included). There was a significant effect of covering on fruit decay in all three trials, but there was no difference between covering 6 to 7 and 3 to 4 weeks prior to harvest. In the sprayed fields, the incidence of decay was $48 \%$ in fruit that were not covered compared with from 6 to $11 \%$ in covered fruit. In the unsprayed field, covering from bloom resulted in $14 \%$ fruit decay compared with 23 to $26 \%$ in the other two cover treatments. In five trials, all covering regimes were included, and the number of fungicide applications varied with time of covering. The number of fungicide applications for the different treatments were: bloom-cover, 0; early-fruit-cover, 1 to 4 ; late-fruit-cover, 2 to 5 ; uncovered, 3 to 6 . The mean incidence of fruit decay at harvest for the five trials (range in parentheses) was 3.4 (2.0 to 4.3), 1.8 (0.4 to 4.0 ), 3.8 (1.8 to 7.7 ), and $16.5 \%$ ( 2.5 to 39.7 ), respectively, for the covering times listed. There were no significant differences in decay after storage $\left(3\right.$ to 7 days at $4^{\circ} \mathrm{C}$ followed by 2 to 4 days at $20^{\circ} \mathrm{C}$ ) among the different covering times in the six experiments where fruit were stored. The results indicate that fungicide applications were not needed if fruit were covered during rainy periods from bloom until the end of harvest, and it was possible to omit 1 fungicide application if the covering period was increased from 3 to 4 weeks to 6 to 7 weeks. The fruit quality was not reduced by increasing the covering period from the normal 3 to 4 weeks in any of the experiments.
\end{abstract}

Additional keywords: bitter rot, brown rot, gray mold, Mucor rot

Fruit rot is one of the most serious problems in production of sweet cherry (Prunus avium L.), and the most common fruit rots in Norwegian sweet cherry orchards are brown rot (Monilinia laxa (Aderh. \& Ruhl.) Honey and gray mold (Botrytis cinerea Pers.:Fr.). Bitter rot (Colletotrichum gloeosporioides (Penz.) Penz. $\&$ Sacc. in Penz.) and Mucor rot (Mucor

Corresponding authors: J. Børve and A. Stensvand E-mail: jorunn.borve@planteforsk.no and arne.stensvand@planteforsk.no

The Ministry of Agriculture and The Norwegian Industrial and Regional Development Fund provided financial support for this research.

Accepted for publication 5 December 2002.

Publication no. D-2003-0310-02R

(C) 2003 The American Phytopathological Society piriformis E. Fisch.) are of less importance but, in certain years and orchards, they can be major causes of fruit decay. In most sweet cherry-growing countries, extensive use of fungicides from bloom until 1 to 2 weeks prior to harvest is necessary to prevent fruit decay. A typical spray schedule in Norway includes one or two applications during bloom, one or two on green fruit, and at least one application when fruit change color.

To prevent fruit cracking due to rain, it is common practice in Norwegian sweet cherry production to place rain shields made of polyethylene or other waterproof, light-transmitting materials over the tree canopies (7). Growers keep the shields on during periods of rain the last 3 to 4 weeks prior to harvest and until the harvest is completed. Fruit-decaying organisms need free water or high relative humidity to infect (10). Excluding precipitation, and thus preventing free water on the fruit by having shields over the tree canopies, should decrease the number of fungal infections. A reduction in fruit decay when a rain shield is used prior to harvest has been reported previously from Switzerland $(14,15)$ and Norway (2). Following a typical spray program in Switzerland, the incidence of fruit decay on sweet cherry trees that were covered during the last 3 weeks prior to harvest was reduced on average from 13 to $3 \%(14,15)$. On unsprayed trees, covering reduced fruit decay on average from 31 to $12 \%$ in 3 years (15). In a sweet cherry orchard in Norway treated with a regular spray program against fruit decay, covering 3 to 4 weeks prior to harvest reduced disease incidence from 48 to $7 \%$ and from 10 to $1 \%$ in uncovered trees in two seasons, respectively (2).

The objectives of the present investigation were to determine the effect of timing of covering with a rain shield on fruit decay and fruit quality at harvest and after storage, and whether or not covering can replace fungicide applications to prevent fruit decay.

\section{MATERIALS AND METHODS}

Two series of experiments were conducted: one to determine the effect of time of covering (either sprayed or unsprayed, but using the same number of fungicide applications for the different covering times), and the other to determine the effects of time of covering in combination with varying the number of fungicide applications (earlier covering, fewer applications). Details about each orchard are given in Table 1.

The investigation of the effect of time of covering was conducted in three orchards in Ullensvang (in Hordaland County, southwestern Norway); Børve and Hesthamar in 1998, and Lofthus in 1999 (Børve 98, Hesthamar 98, and Lofthus 99). All trees received an equal number of growerscheduled fungicide applications at Børve 98 and Hesthamar 98 (two and three applications, respectively, in the two orchards). There were no applications at Lofthus 99. The treatments were (i) covered at time of full bloom (bloom-cover), (ii) covered at time of green fruit (earlyfruit-cover; i.e., 6 to 7 weeks prior to harvest), (iii) covered at yellow fruit stage (late-fruit-cover; i.e., 3 to 4 weeks prior to harvest), and (iv) not covered throughout 
the experiment. Lofthus 99 included all cover treatments, but the bloom-cover treatment was not included at Børve 98 and Hesthamar 98. The experimental design at Børve 98 was a randomized block design with three two-tree replicates of each cover treatment. At harvest, samples of 150 fruit were harvested from each replicate. At Hesthamar 98, the treatments were not repeated. Each rain shield (treatment) covered 12 to 16 trees and, at harvest, four samples of 150 fruit each were harvested from each treatment. The trees at Lofthus 99 were part of a planting system trial. Three different planting distances were used as replicates: $1.5,2.0$, and $3.0 \mathrm{~m}$ within rows and $4 \mathrm{~m}$ between rows, giving a block trial with three replicates of each of four cover treatments. Each replicate consisted of two to four trees, depending on planting distance and size of the trees. At harvest, three samples of 100 fruit each were picked from each replicate.

To investigate if earlier covering could reduce the need for fungicide applications, four commercial orchards were used: Sekse in 1998 and 1999 and Hesthamar in 1999 (Ullensvang), Skolem and Langrud in 1999 (Kongsberg, in Buskerud County, southeastern Norway), and Lardal (in Vestfold County, southeastern Norway). The orchards are referred to as Sekse 98, Sekse 99, Hesthamar 99, Skolem 99, and
Langrud 99. Hesthamar 99 was the same orchard as Hesthamar 98 described above. Four treatments, as described above (bloom, early-fruit, late-fruit, and uncovered), were included in all orchards. A treatment consisted of 4 to 16 trees. The treatments were not replicated at each site. At harvest, four samples of 150 fruit each were harvested from each treatment. No fungicides were applied to bloom-covered trees, early-fruit-covered trees received one to four applications, late-fruit-covered two to five applications, and uncovered trees received three to six applications.

The cover shields were removed during dry periods, except at Børve 98, where they were on from the first time of covering and throughout harvest. However, some growers left the shields on over several days in dry periods, because rain and unstable weather were forecast, but did not necessarily occur. In three of the trials (Sekse 98 and 99 and Hesthamar 99), the growers noted how many times they pulled the shields on and off, because this is labor intensive.

Two different covering systems were used in the experiments, either 1-wire (Børve 98) or 3-wire (all others), depending on the number of wires that supported the rain shields. In the 1-wire system, the plastic sheets were supported by one wire on top of poles. The sheets were tied with ropes to the trunks of trees in the neighboring rows, and the distance from the ground to the edge of the sheets was 1 to $1.5 \mathrm{~m}$. In the 3 -wire system, the plastic sheets were supported by one wire in the middle of each tree row and fastened with hooks to two other wires between the rows. All three wires were positioned at the same height above ground, thus supporting a nearly flat roof. The distance between the roof and the tops of the trees in both systems varied among fields (from less than $0.5 \mathrm{~m}$ to $1.5 \mathrm{~m}$ ), depending on tree height and pole size. Technical details about the systems have been described previously (7). The plastic sheets were either Gepex $(0.1-\mathrm{mm}$ polyethylene from Norfolier, Lillestrøm, Norway) or Rantex (0.25-mm polyethylene from Rantex, Mo i Rana, Norway). The Gepex sheet was used at Lofthus 99, Børve 98, and Sekse 98 and 99, while the Rantex sheet was used at Hesthamar 98 and 99, Skolem 99, and Langrud 99. The size of each cover sheet depended on type of supporting system and tree-by-row distance, and covered from 3 to 16 trees.

At least two of the following fungicides were used in each orchard from time of bloom to late June to early July: bitertanol, iprodione, thiophanate-methyl, tolylfluanid, and triforine (Table 2). Hourly records of temperature, air humidity, precipitation,

Table 1. Description of the sweet cherry orchards where experiments were conducted

\begin{tabular}{lcllccc}
\hline Field & Year tested & Cultivar & Rootstock & Tree spacing $(\mathbf{m})^{\mathbf{y}}$ & Year planted & Training \\
\hline Børve $^{z}$ & 1998 & Van & Seedling & $2.5 \times 4.5$ & 1993 & Slender spindle \\
Hesthamar & $1998-99$ & Sunburst & Colt & $1.0 \times 4.0$ & 1995 & Y-trellis \\
Sekse & $1998-99$ & Van & Colt & $2.8 \times 4.5$ & 1995 & Slender spindle \\
Lofthus & 1999 & Van & Damil & $1.5-3.0 \times 4.0$ & 1991 & Slender spindle \\
Langrud & 1999 & Van & Colt & $2.0 \times 4.0$ & 1995 & Vertical axis \\
Skolem & 1999 & Van & Colt & $2.0 \times 4.0$ & 1994 & Vertical axis \\
\hline
\end{tabular}

y Distance between trees within a row by distance between rows.

${ }^{\mathrm{z}}$ This orchard had a permanent cover supported by a single wire; all others had covers supported by three wires and the covers were removed during dry periods.

Table 2. Fungicides applied to control fruit decay in sweet cherry during the experimental period (bloom to harvest) and date of first cover for the different covering regimes

\begin{tabular}{|c|c|c|c|}
\hline Orchard & Year & Fungicide $^{y}$ & Date of first cover ${ }^{\mathrm{z}}$ \\
\hline Børve & 1998 & Thiophanate-methyl (14 May, 0.75 1), tolylfluanid (24 June, $1.25 \mathrm{~kg}$ ) & 25 June (early-fruit), 18 July (late-fruit) \\
\hline Hesthamar & 1998 & $\begin{array}{l}\text { Thiophanate-methyl (15 May, } 0.43 \text { 1), tolylfluanid (1 June, } 0.45 \mathrm{~kg} \text { ), } \\
\text { iprodione (23 June, } 0.68 \mathrm{l} \text { ) }\end{array}$ & 1 July (early-fruit), 21 July (late-fruit) \\
\hline Hesthamar & 1999 & $\begin{array}{l}\text { Thiophanate-methyl (15 May, } 0.5 \text { 1), tolylfluanid (9 June, } 0.55 \mathrm{~kg} \text { ), } \\
\text { iprodione (3 July, } 0.83 \text { 1) }\end{array}$ & $\begin{array}{l}21 \text { May (bloom), } 28 \text { June (early-fruit), } \\
14 \text { July (late-fruit) }\end{array}$ \\
\hline Sekse & 1998 & $\begin{array}{l}\text { Bitertanol + thiophanate-methyl ( } 9 \text { May, } 0.08 \mathrm{~kg}+0.231) \\
\text { tolylfluanid (18 May, } 0.56 \mathrm{~kg}) \text {, triforine (15 June, } 0.091)\end{array}$ & $\begin{array}{l}4 \text { May (bloom), } 15 \text { June (early-fruit), } \\
14 \text { July (late-fruit) }\end{array}$ \\
\hline Sekse & 1999 & $\begin{array}{l}\text { Thiophanate-methyl (12 May, } 0.35 \text { 1), tolylfluanid ( } 20 \mathrm{May}, 0.56 \mathrm{~kg}) \text {, } \\
\text { tolylfluanid ( } 3 \text { June, } 0.38 \mathrm{~kg} \text { ), triforine (16 June, } 0.16 \text { ), iprodione ( } \mathrm{July} \text {, } \\
0.43 \text { 1), iprodione ( }(\text { July, } 0.64 \text { 1) }\end{array}$ & $\begin{array}{l}7 \text { May (bloom), } 28 \text { June (early-fruit), } \\
14 \text { July (late-fruit) }\end{array}$ \\
\hline Langrud & 1999 & $\begin{array}{l}\text { Thiophanate-methyl (19 May, } 0.75 \text { 1), tolylfluanid ( } 31 \text { May, } 0.75 \mathrm{~kg} \text { ), } \\
\text { iprodione (15 June, } 1.1 \text { 1), iprodione (2 July, } 1.1 \mathrm{l})\end{array}$ & $\begin{array}{l}8 \text { May (bloom), } 29 \text { June (early-fruit), } \\
10 \text { July (late-fruit) }\end{array}$ \\
\hline Skolem & 1999 & $\begin{array}{l}\text { Thiophanate-methyl (19 May, } 0.75 \text { l), tolylfluanid ( } 31 \text { May, } 0.75 \mathrm{~kg} \text { ), } \\
\text { iprodione (15 June, } 1.1 \text { l), iprodione (2 July, } 1.1 \mathrm{l})\end{array}$ & $\begin{array}{l}8 \text { May (bloom), } 29 \text { June (early-fruit), } \\
10 \text { July (late-fruit) }\end{array}$ \\
\hline
\end{tabular}

\footnotetext{
y Date of application and amount active ingredient per hectare in parentheses.
}

${ }^{\mathrm{z}}$ First date when trees were shielded against rain for the three different covering regimes; bloom, early-fruit (6 to 7 weeks before harvest), or late-fruit (3 to 4 weeks before harvest). No fungicides were applied after the date of early-fruit-cover in any of the treatments (Børve 1998, Hesthamar 1998) or fungicides were not applied after the date of bloom, early-fruit, or late-fruit-cover in the respective covering regimes (all others). Products used: thiophanate-methyl = Topsin FL (50\% a.i., KVK Agro A/S); tolylfluanid = Euparen M (50\% a.i., Bayer AG); iprodione = Rovral Akva (50\% a.i., Rhone Poulenc); bitertanol = Baycor (25\% a.i., Bayer AG); and triforine $=$ Saprol (19\% a.i., American Cyanamid Co.). 
and leaf wetness were provided from weather stations (Instrumenttjenesten AS, Ås, Norway) placed within the orchards (Børve 98 and Lofthus 99), approximately $300 \mathrm{~m}$ from the orchard (Sekse 98), or within 10 to $45 \mathrm{~km}$ (all others). The weather stations at Børve 98 and Lofthus 99 had one leaf wetness sensor placed next to the weather station (on the same pole) and additional leaf wetness sensors mounted inside the tree canopies of one covered and one uncovered tree.

The fruit samples were harvested at normal maturity. Samples were harvested arbitrarily from the trees, and each sample contained fruit from the lower, middle, and upper canopy levels. The fruit were sorted into three categories: healthy, decayed, or cracked. Decayed fruit were further sorted by symptoms and signs of brown rot (Monilinia laxa), gray mold (B. cinerea), bitter rot (C. gloeosporioides), Mucor rot (Mucor piriformis), and other rots. Fungal characteristics were examined macroscopically, and the diagnosis was confirmed by microscopy if necessary. Color of healthy fruit was rated on a scale of 1 to 7 , where 1 was light and 7 was dark red (13), and percentage of soluble solids was recorded by a refractometer (Palette PR 101, Atago $\mathrm{CO}$, Tokyo, Japan) in two replicates, each containing 10 fruit. From each replicate, 50 (Sekse 99, Hesthamar 99, Langrud 99, Skolem 99) or 100 (Børve 98, Lofthus 99) apparently healthy fruit (with no disease symptoms) were stored for 3 to 7 days at $4^{\circ} \mathrm{C}$ in a ventilated storage room followed by 2 to 4 days at $20^{\circ} \mathrm{C}$, and then assessed for fruit decay. The same fruit sampled for storage (50 or 100) were weighed at time of harvest to determine individual fruit weight. For Hesthamar 98 and Sekse 98, where no storage samples were picked, 100 healthy fruit from each replicate were weighed.

All data were analyzed statistically using the GLM procedure of SAS (SAS Institute, Cary, NC), and differences among means were determined by the Student Newman Keuls method at $\alpha=0.05$. Incidence of the various diseases and total fruit decay were arcsine-square root transformed prior to analysis. Data from each field were analyzed separately and, because the effect of sample was not significant in any of the fields with parallel sampling under the same cover regime, this effect was excluded from the model.

\section{RESULTS}

At Sekse 98, Sekse 99, and Hesthamar 99, respectively, trees were covered (i) from bloom: 17, 11, and 6 times; (ii) from 6 to 7 weeks prior to harvest: 9,2 , and 2 times; and (iii) from 3 to 4 weeks prior to harvest: 1 time in all three trials. In the experiments, full bloom occurred in early to mid-May and fruit were harvested within the first 2 weeks of August. Monthly means for temperature and precipitation from one weather station in Ullensvang and one in Hokksund in Buskerud County (southeastern Norway), the two regions where the trials were held, are shown in Table 3. The total hours of leaf wetness between full bloom and harvest at Børve 98 were 245, 454, and 717 in earlyfruit-covered, late-fruit-covered, and uncovered trees, respectively. At Lofthus 99, the total hours of leaf wetness between full bloom and harvest were 114, 342, 362, and 456 in bloom-covered, early-fruit-covered, late-fruit-covered, and uncovered trees, respectively. Time from full bloom to harvest was approximately 90 days at both locations. At Lofthus 99, there were more clear and calm nights than at Børve 98 (data not shown), and the sensor under the shield was more frequently wet by dew during the night than the sensor in the canopy of the uncovered tree. The longest leaf wetness period recorded under the shield at Lofthus 99 was $14 \mathrm{~h}$. Most peri-

Table 3. Mean temperature, total precipitation, and number of days with precipitation, from 10 May to 10 August 1998-99

\begin{tabular}{|c|c|c|c|c|c|c|c|c|c|c|c|c|c|}
\hline \multirow[b]{2}{*}{ Location ${ }^{y}$} & \multirow[b]{2}{*}{ Year } & \multicolumn{3}{|c|}{ May (10-31) } & \multicolumn{3}{|c|}{ June (1-30) } & \multicolumn{3}{|c|}{ July (1-31) } & \multicolumn{3}{|c|}{ August (1-10) } \\
\hline & & $\begin{array}{c}\text { Temp. } \\
\left({ }^{\circ} \mathbf{C}\right)\end{array}$ & $\begin{array}{c}\text { Precip. } \\
\text { (mm) }\end{array}$ & $\begin{array}{l}\text { Rain } \\
\text { days }^{z}\end{array}$ & $\begin{array}{c}\text { Temp. } \\
\left({ }^{\circ} \mathbf{C}\right)\end{array}$ & $\begin{array}{c}\text { Precip. } \\
\text { (mm) }\end{array}$ & $\begin{array}{l}\text { Rain } \\
\text { days }\end{array}$ & $\begin{array}{c}\text { Temp. } \\
\left({ }^{\circ} \mathbf{C}\right)\end{array}$ & $\begin{array}{c}\text { Precip. } \\
\text { (mm) }\end{array}$ & $\begin{array}{l}\text { Rain } \\
\text { days }\end{array}$ & $\begin{array}{c}\text { Temp. } \\
\left({ }^{\circ} \mathbf{C}\right)\end{array}$ & $\begin{array}{c}\text { Precip. } \\
\text { (mm) }\end{array}$ & $\begin{array}{l}\text { Rain } \\
\text { days }\end{array}$ \\
\hline Ullensvang & 1998 & 12.0 & 50 & 8 & 12.6 & 84 & 18 & 13.9 & 68 & 21 & 13.9 & 55 & 5 \\
\hline Ullensvang & 1999 & 10.3 & 70 & 18 & 13.4 & 63 & 17 & 15.1 & 66 & 21 & 18.0 & 11 & 5 \\
\hline Hokksund & 1999 & 10.5 & 33 & 10 & 14.0 & 148 & 20 & 17.6 & 28 & 8 & 17.8 & 4 & 3 \\
\hline
\end{tabular}

y Ullensvang Research Centre, located in Hordaland County in southwestern Norway, and Hokksund, located in Buskerud County in southeastern Norway.

${ }^{\mathrm{z}}$ Rain days $=$ days for which $>0.2 \mathrm{~mm}$ rain was recorded.

Table 4. Effect of different covering times on fruit rot incidence at harvest and after storage, and fruit quality at harvest in three different sweet cherry orchards ${ }^{\mathrm{t}}$

\begin{tabular}{|c|c|c|c|c|c|c|c|c|c|c|c|c|c|}
\hline \multirow[b]{2}{*}{ Field, year } & \multirow[b]{2}{*}{$\begin{array}{c}\text { Covering } \\
\text { time }\end{array}$} & \multirow[b]{2}{*}{$\begin{array}{c}\text { Cover on } \\
\text { (days) }\end{array}$} & \multicolumn{7}{|c|}{ Disease incidence $(\%)^{\mathrm{u}}$} & \multicolumn{4}{|c|}{ Fruit quality } \\
\hline & & & $\begin{array}{l}\text { Total } \\
\text { decay }\end{array}$ & $\begin{array}{c}M . \\
\text { laxa }\end{array}$ & $\begin{array}{c}B . \\
\text { cinerea }\end{array}$ & $\begin{array}{c}\text { M. } \\
\text { piri. }\end{array}$ & $\begin{array}{c}C . \\
\text { gloeo. }\end{array}$ & Other & $\begin{array}{c}\text { After } \\
\text { storage }^{v}\end{array}$ & $\begin{array}{c}\text { Cracked } \\
(\%)\end{array}$ & Colorw & $\begin{array}{c}\text { Soluble } \\
\text { solids (\%) }\end{array}$ & $\begin{array}{c}\text { Weight } \\
\text { (g) }\end{array}$ \\
\hline \multirow[t]{3}{*}{ Børve $98^{x}$} & Early fruit & 50 & $8.0 \mathrm{~b}$ & $6.7 \mathrm{~b}$ & $1.1 \mathrm{~b}$ & $0.2 \mathrm{~b}$ & 0 & 0 & $2.7 \mathrm{~b}$ & 22.4 & $6.3 \mathrm{a}$ & 17.7 & $\ldots$ \\
\hline & Late fruit & 27 & $10.9 \mathrm{~b}$ & $7.3 \mathrm{~b}$ & $1.8 \mathrm{~b}$ & $1.3 \mathrm{~b}$ & 0 & 0.4 & $0.7 \mathrm{~b}$ & 22.2 & $6.3 \mathrm{a}$ & 18.4 & $\ldots$ \\
\hline & Uncovered & 0 & $48.2 \mathrm{a}$ & $23.3 \mathrm{a}$ & $13.6 \mathrm{a}$ & $10.7 \mathrm{a}$ & 0 & 0.7 & $8.7 \mathrm{a}$ & 21.5 & $4.0 \mathrm{~b}$ & 17.5 & $\ldots$ \\
\hline$P$ value & $\ldots$ & $\ldots$ & 0.001 & 0.03 & 0.009 & 0.0006 & & 0.4 & 0.002 & 0.9 & 0.001 & 0.6 & $\ldots$ \\
\hline \multirow[t]{3}{*}{ Hesthamar $98^{y}$} & Early fruit & 61 & $5.8 \mathrm{~b}$ & 2.8 & 2.7 & $0 \mathrm{~b}$ & 0 & 0.3 & $\cdots$ & 16.2 & 4.6 & 17.2 & $\ldots$ \\
\hline & Late fruit & 20 & $8.5 \mathrm{~b}$ & 1.8 & 6.3 & $0.3 \mathrm{~b}$ & 0 & 0 & $\ldots$ & 17.3 & 3.6 & 17.1 & $\ldots$ \\
\hline & Uncovered & 0 & $47.8 \mathrm{a}$ & 4.3 & 8.3 & $35.0 \mathrm{a}$ & 0 & 0.2 & $\ldots$ & 19.3 & 3.8 & 15.5 & $\ldots$ \\
\hline$P$ value & 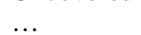 & $\ldots$ & 0.0001 & 0.45 & 0.09 & 0.0001 & & 0.3 & 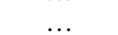 & 0.8 & 0.4 & 0.3 & 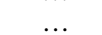 \\
\hline \multirow{4}{*}{ Lofthus $99^{z}$} & Bloom & 61 & $14.1 \mathrm{c}$ & $9.9 \mathrm{~b}$ & 3.0 & 0.2 & $0.6 \mathrm{~b}$ & 0 & 7.0 & 3.4 & 5.7 & $18.0 \mathrm{~b}$ & $10.3 \mathrm{a}$ \\
\hline & Early fruit & 25 & $26.3 \mathrm{~b}$ & $14.8 \mathrm{~b}$ & 1.7 & 0.1 & $9.8 \mathrm{a}$ & 0 & 6.2 & 3.1 & 5.0 & $17.6 \mathrm{~b}$ & $8.5 \mathrm{~b}$ \\
\hline & Late fruit & 21 & $22.7 \mathrm{bc}$ & $15.8 \mathrm{~b}$ & 2.2 & 0.1 & $4.6 \mathrm{~b}$ & 0 & 7.6 & 6.8 & 5.3 & $20.2 \mathrm{a}$ & $8.5 \mathrm{~b}$ \\
\hline & Uncovered & 0 & $35.3 \mathrm{a}$ & $26.9 \mathrm{a}$ & 4.0 & 0.7 & $3.8 \mathrm{~b}$ & 0.6 & 8.0 & 6.4 & 5.5 & $19.0 \mathrm{ab}$ & $9.0 \mathrm{~b}$ \\
\hline$P$ value & $\ldots$ & $\ldots$ & 0.0002 & 0.0007 & 0.3 & 0.2 & 0.0003 & 0.06 & 0.9 & 0.05 & 0.3 & 0.009 & 0.0001 \\
\hline
\end{tabular}

${ }^{\mathrm{t}}$ An equal number of fungicides was applied under the different covering regimes (Børve and Hesthamar 1998) or no fungicides were applied (Lofthus 1999). Mean values denoted with different letters are significantly different $(P<0.05)$ according to the Student Newman Keuls method.

" Disease caused by: M. laxa.$=$ Monilinia laxa, B. cinerea $=$ Botrytis cinerea, M. piri. $=$ Mucor piriformis, C. gloeo.$=$ Colletotrichum gloeosporioides, and Other $=$ fruit decayed by other fungal pathogens.

${ }^{v}$ Disease incidence after storage 3 to 7 days at $4{ }^{\circ} \mathrm{C}$ and 2 to 4 days at $20^{\circ} \mathrm{C}$.

${ }^{\text {w}}$ Fruit color was based on a 1-to-7 scale, where 1 is light and 7 is dark red.

${ }^{x}$ Mean of three replicates of 150 fruit, two fungicide applications.

${ }^{y}$ Mean of four samples of 150 fruit, three fungicide applications.

${ }^{\mathrm{z}}$ Mean of three replicates of 3 by 100 fruit, no fungicide applications. 
ods lasted approximately $10 \mathrm{~h}$, and a total of 11 leaf wetness periods $>6 \mathrm{~h}$ due to condensation occurred from bloom to the end of harvest. The corresponding number of leaf wetness periods $>6 \mathrm{~h}$ in uncovered trees was 37 . For the early-fruit and latefruit-cover treatments, 6 and 5 leaf wetness periods $>6 \mathrm{~h}$, respectively, occurred when the shields were on, and corresponding numbers in uncovered trees were 12 and 9 . For Børve 98, two 1-h leaf wetness periods occurred in the late-fruit-cover treatment and 4 1-h and 1 2-h leaf wetness periods occurred in the early-fruit-cover treatment. The number of leaf wetness periods $>6 \mathrm{~h}$ in uncovered trees for Børve 98 was 31 and 17 when the shields were on in the earlyfruit and late-fruit-cover treatments, respectively.

The most frequently observed fruit decays were those caused by Monilinia laxa and B. cinerea, while C. gloeosporioides, Mucor piriformis, and other fungi, such as Penicillium spp., were observed occasionally. The incidence of Mucor rot was relatively high in 1998, especially in one field (Hesthamar 98). Fruit with symptoms of bitter rot usually were present in very low numbers, with the exception of Lofthus 99. In two trials, the number of fungicide applications was similar between the different covering times (no covering from bloom included), and in one trial no fungicides were applied at all (Table 4). There was a significant effect of covering on fruit decay in all three trials, but there were no differences between covering 6 to 7 and 3 to 4 weeks prior to harvest. In the unsprayed field at Lofthus in 1999, covering from bloom had significantly lower disease incidence than early-fruit-covered and uncovered trees $(P=0.0002)$. After storage, disease incidence in fruit from uncovered trees at Børve 98 was higher than in fruit from covered trees $(P=0.002)$. Stored fruit from the Lofthus 99 field showed no significant difference in decay among any of the treatments.

In five trials, where the number of fungicide applications varied with time of covering, the mean incidence of fruit decay at harvest was $3.4,1.8,3.8$, and $16.5 \%$ for bloom-covered, early-fruit-covered, latefruit-covered, and uncovered fruit, respectively (Fig. 1). There were no significant differences among the covering regimes, but the cover treatments were different from the uncovered one $(P=0.0001)$. In individual trials, there were no significant differences in total decay among the different times of covering (Table 5), but covering significantly reduced decay when compared with no covering in three of the experiments. After storage, the overall mean incidence of decay was 5.8, 4.0, 6.8, and $5.3 \%$ for the treatments as listed above, and there were no significant differences among any of the treatments.

There were only minor differences in fruit quality (cracking, soluble solids, fruit color, and weight) among the different covering times. Covering reduced fruit cracking significantly at Sekse $98(P=$ $0.0001)$, Sekse $99(P=0.0001)$, and Skolem $99(P=0.007)$ compared with uncovered fruit (Table 5). At Hesthamar 99 (Table 5), incidence of cracking in earlyfruit-covered fruit was not significantly different from that in uncovered fruit, but significantly fewer cracked fruit were observed in bloom and late-fruit-covered fruit $(P=0.0008)$. In two orchards (Sekse 99 and Hesthamar 99) (Table 5), fruit were darker when covered at bloom compared with later covering or uncovered fruit $(P=$ 0.002 and 0.0001 , respectively). At Børve 98 (Table 4), uncovered trees had fewer ripe fruit (lighter fruit color) than the covered ones at time of harvest $(P=0.001)$. Sugar content (soluble solids) was significantly lower $(P=0.01)$ in uncovered compared with covered fruit at Sekse 98 (Table

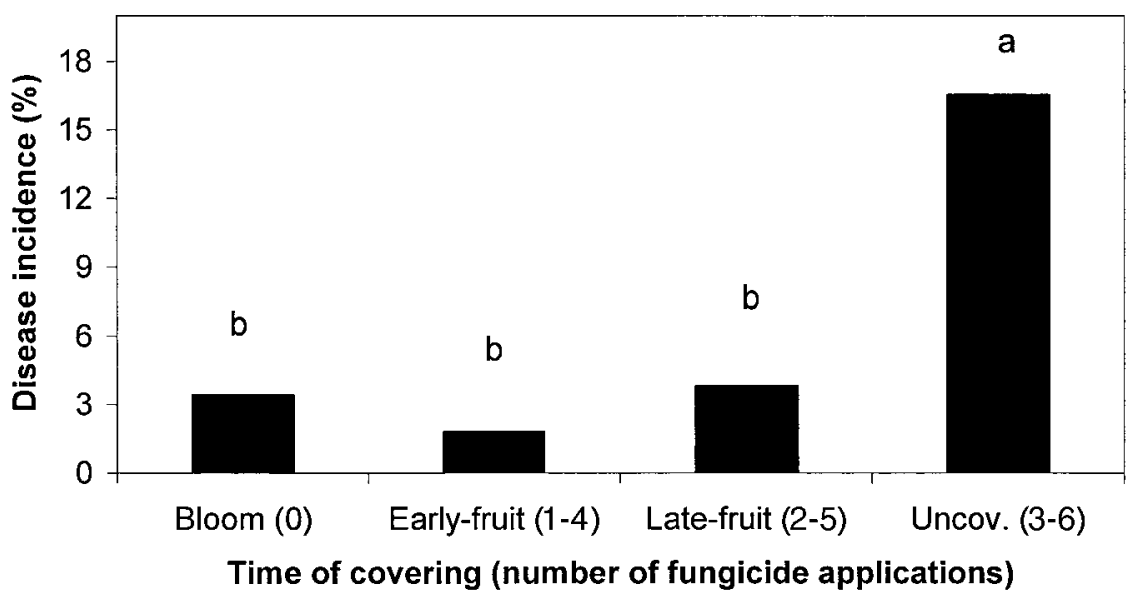

Fig. 1. Effect on fruit decay (mean of five trials) of plastic rain shields above sweet cherry trees during periods of rain, beginning at bloom, 6 to 7 weeks (early-fruit) prior to harvest, 3 to 4 weeks (late-fruit) prior to harvest, or not covered. Number of fungicide applications (in parentheses) varied according to time of covering. Different letters above bars indicate statistically significant differences, based on the Student Newman Keuls method $(P<0.05)$.
5). Soluble solids were higher for fruit with the shortest covering time at Lofthus 99 compared with longer covering $(P=0.009$; Table 4). Fruit weight was higher in the trees covered from bloom than in the other treatments in the Sekse 99 field $(P=$ 0.0001 ; Table 5); whereas, in the Hesthamar 99 field (Table 5), fruit weight was highest in the early cover treatment $(P=$ 0.0001).

\section{DISCUSSION}

These experiments have shown that fruit decay may be greatly reduced if sweet cherry trees are covered with rain shields during rainy periods prior to harvest, and that protecting the fruit from rain may reduce the need for fungicide treatments. No fungicides were needed if fruit were covered during rainy periods from time of bloom until the end of harvest, and it was possible to omit one fungicide application if the normal covering period was increased from 3 to 4 weeks to 6 to 7 weeks. Increasing the covering period and reducing the number of fungicide applications had no detrimental effect on fruit quality.

Experiments in Switzerland $(14,15)$ and Norway (2) have shown a pronounced reduction of fruit decay in sweet cherry covered the last 3 to 4 weeks prior to harvest, but no attempts were made to reduce the number of fungicide applications in covered compared with uncovered trees. As far as we are aware, investigations of covering as a replacement instead of a supplement to fungicide applications have not been reported elsewhere in sweet cherry. It was reported that incidence of Botrytis fruit rot in strawberry was reduced significantly if the crop was grown in large plastic tunnels instead of in the open field, and the use of fungicides against Botrytis spp. could be eliminated (17). The effect on fruit quality when using different covering times in sweet cherry has been reported from Washington $(11,12)$ and California (16) but, to our knowledge, the present investigation is the first to report the effect of extended periods of covering on both fruit decay and fruit quality beginning prior to the typical 3 to 4 weeks before harvest.

Use of plastic rain shields reduced fruit decay in all trials except in the two orchards (Langrud and Skolem) in eastern Norway in 1999. Those orchards were located in a new area for sweet cherry production, and the level of overwintering inoculum within the orchard and from neighboring orchards was probably low. Furthermore, during the most important ripening period in July 1999, the weather was relatively warm and dry. A reduction in disease incidence under cover in six of eight trials indicates that keeping the fruit protected from rain is more effective in preventing fruit decay than use of fungicides, and that the conditions under cover inhibit disease development. 
Leaf wetness was recorded inside the tree canopy under the rain shields at Børve 98 and Lofthus 99. As expected, covering prevented fruit surface wetness due to precipitation, but condensation occurred on trees under the shields during several clear nights at the Lofthus 99 site. More overcast days occurred in 1998, and fewer condensation events. More hours of wetness due to condensation in 1999 may partly explain why the difference in fruit decay between covered and uncovered fruit was relatively small at Lofthus 99. Thus, it is important to be aware that leaving the shields on during clear nights may increase the possibility for condensation and, subsequently, for infection. Temperatures in covered trees during the night ranged from 5 to $15^{\circ} \mathrm{C}$, but were most often between 10 and $15^{\circ} \mathrm{C}$ (data not shown). It was reported from Ontario, Canada that Monilinia fructicola needs 6 to $12 \mathrm{~h}$ of wetness for $10 \%$ fruit infection to occur in sweet cherry at $15^{\circ} \mathrm{C}$ (1). Thus, if the infection time for M. laxa is approximately the same, some of the periods with wetness due to condensation were probably long enough to cause infection at Lofthus in 1999.
There was no significant difference in fruit decay between early-fruit-cover and late-fruit-cover treatments in the two fields where the different treatments received the same number of fungicide applications (two or three in the two experiments, respectively). $M$. fructicola colonizes sweet cherry fruit during the entire fruit development period (9), and the same has been found for M. laxa in plum and peach (6). However, the susceptibility of sweet cherry fruit to $M$. fructicola increases during the ripening period (9). Plum and peach fruit were resistant to infection by $B$. cinerea until 2 to 3 weeks prior to harvest (6). Thus, for the main pathogens, there seems to be an increase in susceptibility of stone fruit toward harvest, and this may partly explain the small or nonexistent difference in disease incidence at harvest between early and late covering.

Fruit quality was not adversely affected by covering. When single branches of sweet cherry were covered with aluminum foil bags or fiberglass, no reduction in the content of soluble solids in covered fruit was reported $(12,16)$. Likewise, there were no negative effects on fruit quality or yield when the trees were covered with rain shields 3 to 4 weeks prior to harvest $(2,3)$. Some reports indicated a delayed ripening under shields if covered permanently during 3 to 4 weeks prior to harvest $(8,11,18)$. Delayed ripening was explained by higher temperature under covered trees (8). However, the opposite was reported from Israel; sweet cherry fruit that had been under permanent plastic cover from approximately 1 week prior to bloom to harvest were advanced in maturity and size at harvest, and both shoot length and leaf area in trees under cover were higher compared with noncovered trees (19). Increased fruit size also was observed when sweet cherry fruit were covered for 7 weeks (11) or 3 to 6 weeks $(4,5)$ prior to harvest. In a previous report from Norway (3) and in the current experiments, there was no delay in fruit color development on covered trees. Even at Børve 98, where fruit were covered for 50 days, there was no reduction in color. In fact, in that orchard, uncovered fruit were actually lighter red in color. This may be because most uncovered fruit that had ripened early were decayed. Thus, the number of healthy fruit was small, and they were not fully ripe at the time of assessment. In three of six trials, fruit cov-

Table 5. Effect of different covering times on fruit rot incidence at harvest and after storage, and fruit quality at harvest in five different sweet cherry orchards $^{\mathrm{v}}$

\begin{tabular}{|c|c|c|c|c|c|c|c|c|c|c|c|c|}
\hline \multirow[b]{2}{*}{$\begin{array}{l}\text { Field, year, } \\
\text { covering time }\end{array}$} & \multirow[b]{2}{*}{ No. ${ }^{x}$} & \multirow[b]{2}{*}{$\begin{array}{c}\text { Cover on } \\
\text { (days) }\end{array}$} & \multicolumn{6}{|c|}{ Disease incidence $(\%)^{\mathrm{w}}$} & \multicolumn{4}{|c|}{ Fruit quality } \\
\hline & & & Total & $\begin{array}{c}M . \\
\text { laxa }\end{array}$ & $\begin{array}{c}B . \\
\text { cinerea }\end{array}$ & $\begin{array}{c}\text { M. } \\
\text { piri. }\end{array}$ & Other & $\begin{array}{c}\text { After } \\
\text { storage }^{\mathrm{y}}\end{array}$ & $\begin{array}{c}\text { Cracked } \\
(\%)\end{array}$ & Color $^{\mathrm{z}}$ & $\begin{array}{c}\text { Soluble } \\
\text { solids (\%) }\end{array}$ & $\begin{array}{l}\text { Weight } \\
\text { (g) }\end{array}$ \\
\hline \multicolumn{13}{|l|}{ Sekse, 1998} \\
\hline Bloom & 0 & 58 & $3.7 \mathrm{~b}$ & 1.3 & $1.9 \mathrm{~b}$ & $0 \mathrm{~b}$ & 0.5 & $\ldots$ & $4.3 \mathrm{~b}$ & $6.1 \mathrm{a}$ & $21.5 \mathrm{a}$ & 9.5 \\
\hline Early-fruit & 2 & 39 & $4.0 \mathrm{~b}$ & 1.0 & $2.2 \mathrm{~b}$ & $0 \mathrm{~b}$ & 0.8 & $\ldots$ & $6.7 \mathrm{~b}$ & $4.0 \mathrm{~b}$ & $22.5 \mathrm{a}$ & 8.4 \\
\hline Late-fruit & 3 & 24 & $7.7 \mathrm{~b}$ & 1.8 & $4.0 \mathrm{~b}$ & $0.5 \mathrm{~b}$ & 1.3 & $\ldots$ & $9.7 \mathrm{~b}$ & $5.3 \mathrm{ab}$ & $20.7 \mathrm{a}$ & 9.1 \\
\hline Uncovered & 3 & 0 & $39.7 \mathrm{a}$ & 8.2 & $23.0 \mathrm{a}$ & $7.0 \mathrm{a}$ & 1.5 & $\ldots$ & $52.5 \mathrm{a}$ & $3.8 \mathrm{~b}$ & $18.2 \mathrm{~b}$ & 8.4 \\
\hline$P$ value & $\ldots$ & $\ldots$ & 0.0001 & 0.05 & 0.0001 & 0.0001 & 0.5 & $\ldots$ & 0.0001 & 0.004 & 0.01 & 0.2 \\
\hline \multicolumn{13}{|l|}{ Sekse, 1999} \\
\hline Bloom & 0 & 48 & $3.0 \mathrm{~b}$ & $1.3 \mathrm{a}$ & $1.4 \mathrm{~b}$ & 0 & 0.3 & 9.0 & $2.7 \mathrm{bc}$ & $5.6 \mathrm{a}$ & 18.1 & $10.3 \mathrm{a}$ \\
\hline Early-fruit & 4 & 22 & $0.7 \mathrm{~b}$ & $0 \mathrm{~b}$ & $0.7 \mathrm{~b}$ & 0 & 0 & 4.5 & $2.5 \mathrm{c}$ & $3.8 \mathrm{~b}$ & 17.5 & $8.7 \mathrm{bc}$ \\
\hline Late-fruit & 5 & 13 & $2.7 \mathrm{~b}$ & $0.2 \mathrm{ab}$ & $2.5 \mathrm{~b}$ & 0 & 0 & 14.0 & $8.2 \mathrm{~b}$ & $4.0 \mathrm{~b}$ & 18.2 & $8.9 \mathrm{~b}$ \\
\hline Uncovered & 6 & 0 & $20.5 \mathrm{a}$ & $0.2 \mathrm{ab}$ & $18.7 \mathrm{a}$ & 0.7 & 1.0 & 5.5 & $26.0 \mathrm{a}$ & $3.8 \mathrm{~b}$ & 16.0 & $8.4 \mathrm{c}$ \\
\hline$P$ value & $\ldots$ & $\ldots$ & 0.0001 & 0.04 & 0.0001 & 0.07 & 0.2 & 0.2 & 0.0001 & 0.002 & 0.18 & 0.0001 \\
\hline \multicolumn{13}{|l|}{ Langrud, 1999} \\
\hline Bloom & 0 & 91 & 3.8 & $0 \mathrm{~b}$ & 2.0 & 0 & 1.8 & 7.0 & 7.5 & $5.1 \mathrm{a}$ & 18.0 & $7.6 \mathrm{a}$ \\
\hline Early-fruit & 2 & 35 & 1.5 & $0 \mathrm{~b}$ & 0.7 & 0 & 0.9 & 6.5 & 7.8 & $3.5 \mathrm{~b}$ & 17.6 & $7.0 \mathrm{~b}$ \\
\hline Late-fruit & 3 & 21 & 1.8 & $0.7 \mathrm{a}$ & 0.2 & 0 & 1.0 & 11.0 & 10.2 & $3.8 \mathrm{~b}$ & 17.8 & $7.3 \mathrm{ab}$ \\
\hline Uncovered & 4 & 0 & 2.5 & $0 \mathrm{~b}$ & 1.0 & 0 & 1.5 & 7.0 & 21.5 & $4.6 \mathrm{ab}$ & 18.2 & $7.3 \mathrm{ab}$ \\
\hline$P$ value & $\ldots$ & $\ldots$ & 0.4 & 0.003 & 0.4 & $\ldots$ & 0.4 & 0.7 & 0.1 & 0.01 & 0.9 & 0.04 \\
\hline \multicolumn{13}{|l|}{ Skolem, 1999} \\
\hline Bloom & 0 & 91 & 2.0 & 0 & 1.9 & 0 & 0.2 & 3.5 & $0.7 \mathrm{~b}$ & 6.5 & 18.3 & 7.0 \\
\hline Early-fruit & 2 & 35 & 0.4 & 0 & 0.2 & 0 & 0.2 & 1.5 & $0.8 \mathrm{~b}$ & 5.8 & 18.5 & 7.4 \\
\hline Late-fruit & 3 & 21 & 4.3 & 1.2 & 3.2 & 0 & 0 & 0 & $0.2 \mathrm{~b}$ & 6.6 & 19.0 & 7.3 \\
\hline Uncovered & 4 & 0 & 7.0 & 0.3 & 6.7 & 0 & 0 & 3.0 & $3.2 \mathrm{a}$ & 6.6 & 18.2 & 7.4 \\
\hline$P$ value & $\ldots$ & $\ldots$ & 0.1 & 0.3 & 0.08 & $\ldots$ & 0.4 & 0.4 & 0.007 & 0.1 & 0.7 & 0.7 \\
\hline \multicolumn{13}{|l|}{ Hesthamar, 1999} \\
\hline Bloom & 0 & 41 & $4.3 \mathrm{~b}$ & 0.4 & 3.0 & 1.0 & 0 & 3.5 & $2.3 \mathrm{c}$ & $6.6 \mathrm{a}$ & 19.0 & $9.5 \mathrm{~b}$ \\
\hline Early-fruit & 1 & 22 & $2.5 \mathrm{~b}$ & 0 & 2.0 & 0.5 & 0 & 3.5 & $10.7 \mathrm{ab}$ & $5.8 \mathrm{~b}$ & 17.8 & $10.5 \mathrm{a}$ \\
\hline Late-fruit & 2 & 13 & $2.5 \mathrm{~b}$ & 0.2 & 2.0 & 0.2 & 0.2 & 2.0 & $7.0 \mathrm{bc}$ & $4.5 \mathrm{c}$ & 17.6 & $9.9 \mathrm{~b}$ \\
\hline Uncovered & 3 & 0 & $12.9 \mathrm{a}$ & 2.0 & 8.2 & 2.3 & 0.4 & 5.5 & $15.3 \mathrm{a}$ & $5.0 \mathrm{c}$ & 18.8 & $8.8 \mathrm{c}$ \\
\hline$P$ value & $\ldots$ & $\ldots$ & 0.02 & 0.3 & 0.06 & 0.2 & 0.4 & 0.7 & 0.0008 & 0.0001 & 0.16 & 0.0001 \\
\hline \multirow{4}{*}{\multicolumn{13}{|c|}{$\begin{array}{l}\text { For each field and year, means denoted by different letters are significantly different }(P<0.05) \text { according to the Student Newman Keul } \\
\text { method. }\end{array}$}} \\
\hline & & & & & & & & & & & & \\
\hline & & & & & & & & & & & & \\
\hline & & & & & & & & & & & & \\
\hline 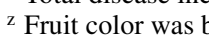 & & & & & & & & & & & & \\
\hline
\end{tabular}


ered at bloom were darker in color at harvest and, in two of the trials, fruit weight was higher compared with the other covering regimes.

A major disadvantage of extending the time of covering is the extra labor required to pull the covers on and off. Furthermore, extra labor may be required to prevent the covers from tearing during periods of strong winds. By extending the covering period by only 2 to 3 weeks beyond the standard 3 to 4 weeks prior to harvest, it is possible to save 1 or 2 fungicide applications without increasing the risk for additional fruit decay. There is a growing concern about pesticide residues among consumers, and fungicides applied late in the season increase the possibility for chemical residues in the fruit. Furthermore, several fungicides leave visible residues on the fruit surface for a long time after application, which may reduce the market value. An elimination of one or two applications prior to harvest will greatly reduce the possibility for visible fungicide residues on the fruit surface. In organic production systems, chemical treatments cannot be used to prevent fruit decay and, in wet seasons, yield losses can be high. The present investigation has demonstrated the possibility for growing sweet cherry fruit without fungicide applications by covering the trees during rain periods beginning at bloom. Organically grown fruit often is sold at a higher price than fruit from conventional or integrated production, which may offset the expense of covering and uncovering the trees.

\section{ACKNOWLEDGMENTS}

We thank the growers E. Børve, T. Hesthamar, A. Langrud, T. Sekse, and K. Skolem for providing trees for the experiments and assistance with covering and spraying; and the technicians at Ullensvang Research Centre and grower advisor J. Meland for their help.

\section{LITERATURE CITED}

1. Biggs, A. R., and Northover, J. 1988. Early and late-season susceptibility of peach fruits to Monilinia fructicola. Plant Dis. 72:1070-1074.

2. Børve, J., and Meland, M. 1998. Rain cover protection against cracking of sweet cherries. I. The effects on marketable yield. Acta Hortic. 468:449-453.

3. Børve, J., and Meland, M. 1998. Rain cover protection against cracking of sweet cherries. II. The effects on fruit ripening. Acta Hortic. 468:455-458

4. Cline, J. A., Meland, M., Sekse, L., and Webster, A. D. 1995. Rain-induced fruit cracking of sweet cherries: II Influence of rain covers and rootstocks on cracking and fruit quality. Acta Agric. Scand. Sect. B Soil Plant Sci. 45:224-230.

5. Cline, J., and Webster, T. 1994. Cherries under wraps. Grower 121 (24):16-17.

6. Fourie, J. F., and Holz, G. 1987. Infection and decay of stone fruit by Botrytis cinerea and Monilinia laxa at different stages after anthesis. Phytophylactica 19:45-46.

7. Meland, M., and Skjervheim, K. 1998. Rain cover protection against cracking for sweet cherry orchards. Acta Hortic. 468:441-447.

8. Meli, T., Riesen, W., and Widmer, A. 1984. Protection of sweet cherry hedgerows with polyethylene films. Acta Hortic. 155:463-467.

9. Northover, J., and Biggs, A. R. 1990. Susceptibility of immature and mature sweet and sour cherries to Monilinia fructicola. Plant Dis. 74:280-284.

10. Ogawa, J. M., Zehr, E. I., Bird, G. W., Ritchie, D. F., Uriu, K., and Uyemoto, J. K. 1995. Compendium of Stone Fruit Diseases. American Phytopathological Society, St. Paul, MN.
11. Opperman, D. 1988. Cherry "umbrella" tried for protection against frost, wind, and rain. Part 1. Fruit quality results. Goodfruit Grower 39(4):26-30.

12. Patten, K. D., and Proebsting, E. L. 1986 Effect of different artificial shading times and natural light intensities on the fruit quality of 'Bing' sweet cherry. J. Am. Soc. Hortic. Sci. 111:360-363.

13. Planton, G. 1995. Cerise: un code coleur pour améliorer la qualité à la rècolte. [Cherries: a color code to improve crop quality.] Centre technique interprofessionnel des fruits et legumes France. Infos No. 112:38-41.

14. Rüegg, J., Höhn, H., and Schwizer, T. 2000 Regenschutzfolien in der biologischen und integrierten Tafelkirschenproduktion. Teil I Einfluss auf Krankheiten, Schädlinge, Mikroklima und Ertrag. Schweiz. Z. Obst Weinbau 136:64-67.

15. Rüegg, J., and Siegfried, W. 1993. Integrierte Obstproduktion: Neues zur Blüten- und Frucht-Monilia. Schweiz. Z. Obst Weinbau 129:620-624.

16. Ryugo, K., and Intrieri, C. 1972. Effect of light on growth of sweet cherry (Prunus avium L.) fruits. J. Am. Soc. Hortic. Sci. 97:691-694.

17. Xiao, C. L., Chandler, C. K., Price, J. F., Duval, J. R., Mertely, J. C., and Legard, D. E. 2001. Comparison of epidemics of Botrytis fruit rot and powdery mildew of strawberry in large plastic tunnel and field production systems. Plant Dis. 85:901-909.

18. Zbinden, W. 1988. Regenschutz für Kirschen - Gesunde Tafelfrüchte. Schweiz. Z. Obst Weinbau 124:364-365.

19. Zilkah, Z., David, I., Yeselson, Y., Moreshet, S., Gussakovsky, E. E., Ratner, K., and Shahak, Y. 1997. Advanced maturity and improved size of 'Burlat' and 'Chinook' sweet cherry fruits under UV-absorbing plastic. Pages 320-325 in: International Congress for Plastics in Agriculture. CIPA Proceedings. S. Ben-Yehoshua, ed. Laser Pages Publishing Ltd., Jerusalem, Israel. 